MedieKultur | Journal of media and communication research | ISSN 1901-9726

\title{
Mediatization and cultural change
}

\section{Stig Hjarvard and Line Nybro Petersen}

\author{
MedieKultur 2013, 54, 1-7
}

Published by SMID | Society of Media researchers In Denmark | www.smid.dk The online version of this text can be found open access at www.mediekultur.dk

\section{"Culture is ordinary"}

In his 1958 essay 'Culture is Ordinary', Raymond Williams gave a condensed statement of his view on culture, one that came to inspire a new way of studying culture in society: "We use the word culture in these two senses: to mean a whole way of life - the common meanings, to mean the arts and learning - the special processes of discovery and creative effort" (Williams, 1958, p. 4). Williams not only combined an anthropological notion of culture as everyday life with an artistic view of culture as distinct representational and knowledgebuilding artifacts and practices; he also insisted on their mutual interdependency. In doing so, he pointed to the necessity of understanding all cultural artifacts and practices - from popular media to the finest art, from everyday rituals to scientific endeavors - in their social and material contexts, without lessening their creative and intellectual dimensions.

Raymond Williams did not intend his dictum of "culture is ordinary" to reduce culture to the humdrum, to everyday life. On the contrary, he wished to insist on the creative and intellectual dimensions of ordinary people's lives and at the same time to suggest a political vision of a common culture in which everyone could participate and fulfill his or her creative and intellectual potential. He resisted the notions of 'the masses' and 'mass culture', saying "there are in fact no masses, but only ways of seeing people as masses" (Williams, 1958, p. 11). His broad conception of culture did not restrain him from taking a critical stance toward aspects of his contemporary culture. He neither respected the use of culture to display traditional status hierarchies nor did he regard as attractive the culture of the new class of commercial 
communication specialists, which took a functional approach to a mass audience: "The new cheapjack is in offices with contemporary décor, using scraps of linguistics, psychology and sociology to influence what he thinks of as the mass mind" (p. 7; original emphasis).

More than half a century later, Williams' holistic and critical approach to culture is just as - if not more - relevant for the study of cultural transformations. In addition to a globalization and commercialization of culture, we are also experiencing a mediatization of culture, which has brought both everyday culture and high arts into new social contexts. This not only makes them available to a larger portion of society but also transforms the very nature of these cultural practices. Social and material conditions of culture are important as a context for explaining cultural phenomena, yet culture has - also due to the media - experienced integration into new social and material practices as well. If we understand the mediatization of culture to mean the various processes through which culture is influenced by the modus operandi of the media (i.e. the media's technological, institutional, and aesthetic modes of operation; Hjarvard, 2013a), then media have become important facilitators of cultural experience. They have acquired the status of cultural institutions (e.g. public service broadcasting, Facebook, etc.) and have become cultural artifacts in their own rights. In addition, cultural practices in other domains (e.g. religion; Petersen, 2012) become dependent on the media and their various affordances. Mediatization theory is particularly well suited for addressing such changes due to its focus on long-term transformations. By shifting focus from 'mediation' (i.e. the concrete acts of communication through media) to 'mediatization' (Hjarvard, 2013b), mediatization theory has provided new impetus for examining the structural influence of media on a variety of cultural phenomena.

Mediatization theory suggests that growing media authority and the integration of media into nearly all cultural practices evoke cultural change, yet the outcome of this is highly variable and dependent on the context in question. In this special issue of MedieKultur, we wish to explore the many ways in which media are embedded in cultural transformation. The aim is both to substantiate the theory of mediatization through empirical analysis and provide a richer understanding of the role of the media in current cultural changes. Following Williams' broad and integrated approach to culture, we offer articles concerning culture as artistic artifacts and common experiences of everyday life - not to mention the interconnections between these domains.

\section{Cultural transformations}

More specifically, this special issues deals with cultural artifacts such as audiobooks, graffiti, and newspapers and cultural experiences such as visiting museums, buying organic food online, receiving health advice, participating in an activist organization, and journalistic work. Throughout, it attempts to grasp both media's role in cultural transformations and the nature of these transformations. Across the diverse cultural phenomena considered by the eight articles in the thematic section of this issue, we find common tenden- 
cies in media's role in cultural change: (1) When various forms of subcultures try to make use of media for their own purposes, they often become (re-)embedded into mainstream culture; (2) National cultural policies often serve as levers for increased mediatization; (3) Mediatization involves a transformation of the ways in which authority and expertise are performed and reputation is acquired and defended; and (4) Technological developments shape the media's affordances and thus the particular path of mediatization.

Although subcultures or more restricted cultural practices may feel encouraged or forced to make use of media, this process may cause them to become gradually intertwined with mainstream culture. In such cases, mediatization is a process in which the fringe areas of cultural life become influenced by the logics of mainstream media. In their article 'The Mediatization of Deviant Subcultures', Kameliya Encheva, Olivier Driessens, and Hans Verstraeten offer an analysis of media practices related to graffiti and skater cultures in Belgium. They argue that, as the practices within these subcultures become immersed in media culture, the oppositional image and rebellious nature of this subculture are challenged and become increasingly mainstreamed. Similarly, Mikkel Eskjær's article 'The Mediatization of Ethical Consumption' points toward mainstreaming as an unintended outcome of mediatization. Using a case study of the Danish Aarstiderne company, which specializes in organic fruit and vegetables, he demonstrates how the movement of ecology and sustainable consumption into an online world transforms the image of ecology from something hippie and anti-modern to something modern and perhaps even trendy. Mediatization of sustainable consumption, Eskjær argues, reveals a paradox: On the one hand, the experience of Aarstiderne illustrates how mediatization is a vehicle for the mainstreaming of ethical consumption, making it more rationalized and commercialized with the help of online logistics and marketing. On the other hand, mediatization of ethical consumption also promises the consumer a dissociation from traditional forms of commodified mass consumption.

Several of the articles in this issue touch upon the issue of general public and cultural policies either as explicit or implicit factors in the shaping of mediatization. Mediatization is thus a process embedded in political and cultural power structures and is sometimes imposed on cultural practices and institutions, for instance through general public policies to promote information and communication technologies (ICT) or cultural policies that use digital media to modernize cultural institutions such as museums. Cultural entrepreneurs and institutions, however, are themselves seeking to actively take advantage of the media. As such, the push toward mediatization in the realm of culture is often a complex mix of developments in the media (including new forms of user/audience behavior), of national cultural policies, and of cultural entrepreneurs' ability to use media to project their own agendas. Mediatization should not be understood as a linear process through which the media simply impose their logic on the cultural realm; the process is, rather, highly contextualized and dependent on the sensitivity of cultural practices to general social pres- 
sures toward mediatization as well as on internal possibilities for using the media for various cultural purposes.

Kim Sawchuk's article 'Tactical mediatization and activist ageing: pressures, push-backs, and the story of RECAA' focuses on a group of elderly activists in Canada who work to combat elder abuse. In her analysis, Sawchuk emphasizes how the group is pressed to integrate media into its work, in part due to the requirements of public funding options available for such activist and community work, at the same time as the activists are embracing opportunities for using digital media to digitize their memories. Sawchuk understands these processes of mediatization as strategic and tactical mediatization respectively. Strategic mediatization concerns the general societal pressures to incorporate media and digital technologies while tactical mediatization reflects the deliberate and considered response of social actors, in this case elderly activists, to retain their own agency and prerogatives while accommodating to some of the external pressures of strategic mediatization.

Museums were once national collections of either high arts or cultural heritage, but due to mediatization, museums are increasingly defining themselves in terms of the experiences they provide their audiences. As Maja Rudloff argues in her article on 'The Mediatized Museum', three keywords have come to dominate cultural policies concerning museums: user experience, interactivity, and participation. With digital media, a visit to a museum is no longer synonymous with a visit to the physical exhibition but may include an online tour and interaction with the museum's virtual exhibitions and resources. The mediatized museum also (re-)introduces questions concerning authenticity in artwork and experience. In a digital world, the difference between original and copy seems to be eroding, and the display and experience of original art in museums may gradually be displaced by the viewing of copies on computer monitors.

Mediatization is also implicated in the long-term transformation of cultural authority and in changing the performative requirements for producing authority and representing expertise. In her historical analysis "Barbarous Cruelty at the British Museum": Mediatization, Authority and Reputation in Nineteenth Century England', Allison Cavanagh addresses how, in late nineteenth century England, newspapers emerged as social and cultural powers involved in the negotiation of public authority and reputation. Using as a case study a particular incident at the British Museum as represented in The Times, she demonstrates the ways in which moral authority were publicly negotiated and how particular actors from lower social classes were able to use the newspaper to defend their reputations by appealing to its readership's moral values of respectability. She thus discerns a double pattern of mediatization of moral authority and moralization of the media.

In her article on 'Health on Television, From Doctor to Health Guru', Christa Lykke Christensen documents how earlier television programs addressing questions of health and disease focused on professional medical expertise of illness and public measures for enhancing health conditions in general. Today, however, such programs have become part of television's factual prime time entertainment, and health has become represented as a 
question of individual entrepreneurship. In conjunction with this change in the conception of health, experts and expertise must be performed in new ways to acquire authority. Today, experts are know-how specialists who perform as individual coaches to promote quick change of individual behavior and lifestyle. Through this process, the demands of the television industry come to co-construct the notion of health together with broader cultural shifts in notions of the body and individualism.

The transformative capacity of media technologies is reflected in several of the articles. In particular, the concept of technological affordances has come to play an important role in the analysis of how the material aspects of the media may influence and co-structure symbolic representation and social interaction. James Gibson's (1979) concept of affordances originated in the field of perception psychology and has subsequently been introduced in technology and media studies by Norman (1988) and Hutchby $(2001,2003)$ and further integrated into mediatization theory by Hjarvard (2013a). From this perspective, we may understand the media's affordances as the set of potential uses that facilitate, limit, and structure communication and action through these media. Affordances are materially founded in media as technological artifacts, are institutionally circumscribed, and are perceptually embodied by users and audiences.

Iben Have and Birgitte Stougaard Pedersen's article 'Sonic Mediatization of the Book: Affordances of the Audiobook' makes use of the concept of affordance to understand the new ways of using audiobooks. The audiobook has previously been understood as a book medium confined to people with reading deficiencies, e.g. blind people, children, and people with dyslexia. Today, it has proliferated and transformed the reading experience for a much wider audience, turning it into a listening practice that in some respects resembles music and radio listening. The quiet solitude of reading has thus been partially replaced by listening to books accompanying other practices like gardening, driving, exercising, etc. Through its affordances such as tone of voice, narration, and the immateriality of the MP3 file, the audiobook is transforming the experience of literature and moving the cultural world of books closer to the general media culture.

Similarly, Aske Kammer makes use of the concept of affordance in his article on 'The Mediatization of Journalism' in order to understand how a changing media environment is influencing existing media practices, in this case the practices of journalism. He discerns four trends in contemporary journalism: the use of affordances of news websites (instantaneity, multimodality, interactivity, and hypertextuality); a radical commercialization; the participation of audiences; and a multi-skilling of journalists' work. Applying an institutional perspective, Kammer distinguishes between the media as an institution and journalism as a particular profession or institution. Due to a general process of mediatization, journalism as a specific professional culture is under pressure to accommodate to the requirements of the media, and as a consequence, the profession of journalism is moving from an occupational type of profession to an organizational type of profession. 
Much has changed since Raymond Williams inspired a new approach to the study of media, culture, and society. Processes of globalization, commercialization, and mediatization have changed not only the media landscape but also the culture of everyday life and the cultures of creative and intellectual endeavor. Through these processes, culture has become ordinary in Williams' sense of the word, though perhaps in an even more pronounced sense than he could have anticipated. As the studies in this issue of MedieKultur demonstrate, mundane practices of everyday life - such as buying food, eating, drinking, and exercising - are increasingly addressed in public and discursively changed by various forms of media. At the same time, both mass media and digital media have made cultural experiences - from the artifacts of museums to the subcultures of the street - globally accessible, and interactive media increasingly allow everyone to contribute to cultural production and exchange. Formerly separate cultural domains like the reading of literature and news journalism are increasingly being integrated into a converging media environment.

The evolving media system may potentially make Williams' vision of a richer and more democratic culture possible at the same time as trends also point toward growing cultural segmentation and commercialization. Williams himself was very critical of anti-modern sentiments among his contemporaries, who postulated that the pre-industrial culture of the past was preferable to the emerging culture of modernity. In continuation of Williams' position, the mediatization of culture as a process of high modernity may have many democratic benefits, for instance the opening up cultural spheres that were previously restricted to elite audiences. However, combinations of technological affordances and commercial pressures do not always support the development of a "digital commons" (Murdock 2005) but may, on the contrary, transform cultural experiences into commercial commodities for particular audiences. The highly professionalized "cheapjacks" of the digital era are no longer satisfied with aggregating a mass audience but instead use sophisticated techniques to differentiate and target media products at segmented audiences. Although this may increase the value of cultural products for the individual user in question, it may also disintegrate a common cultural public sphere and diminish the notion of cultural artifacts as common goods. Questions concerning the positive or negative outcomes of mediatization cannot, however, be answered on a general level; they must be addressed through an analysis of the specific contexts in which mediatization occurs and by explicating the normative framework of such evaluations. As far as such analyses are concerned, Williams' critical perspective is more relevant than ever for our understanding of cultural transformation in the age of mediatization.

\section{Open section}

Finally, the open section of this issue of MedieKultur includes Dermot Heaney's article "'Don Fabio" and the taming of the three lions: The discursive construction of a foreign England manager's identity in the sports online written media'. Heaney considers the appointment 
of a foreign manager to coach the national football team from the perspective of discursive identity construction. Reflecting current trends in Critical Discourse Analysis, he combines qualitative close analysis and quantitative analysis of online versions of newspaper articles to identify salient and consistent aspects of identity constructions. The data, corresponding to three phases of Capello's first two years of tenure, is examined with reference to transitivity, lexis, and narrative identity construction. The analysis shows how the media response to Capello's appointment follows a trajectory of rejection, expectation, and 'naturalisation'.

\section{References}

Gibson, J.J. (1979). The Ecological Approach to Visual Perception. Boston: Houghton Mifflin.

Hjarvard, S. (2013a). The Mediatization of Culture and Society. London: Routledge.

Hjarvard, S. (2013b, in press). From mediation to mediatization: the institutionalization of new media. In

A. Hepp \& F. Krotz (Eds.), Mediatized Worlds: Culture and Society in a Media Age. New York: Palgrave.

Hutchby, I. (2001). Technologies, texts and affordances. Sociology, 35(2), 441-456.

Hutchby, I. (2003). Affordances and the analysis of technologically mediated interaction: a response to Brian

Rappert. Sociology, 37(3), 581-589.

Murdock, G. (2005). Building the digital commons: public broadcasting in the age of the internet. In P. Jauert

\& G.F. Lowe (Eds.), Cultural Dilemmas of Public Service Broadcasting (pp. 213-230). Gothenburg: Nordicom.

Norman, D.A. (1988). The Psychology of Everyday Things. New York: Basic Books.

Petersen, L.N. (2012). Wicked Angels, Adorable Vampires. Religion, amerikanske serier og danske teenagere

(Ph.D. dissertation). Copenhagen: Faculty of Humanities, University of Copenhagen.

Williams, R. (1958 [1989]). Culture is ordinary. In R. Williams (Ed.), Resources of Hope, Culture, Democracy, Socialism (pp. 3-18). London: Verso.

Stig Hjarvard

Professor, PhD

Film and media Studies Section

Department of Media, Cognition and Communication

University of Copenhagen, Denmark

stig@hum.ku.dk

Line Nybro Petersen

External lecturer, $\mathrm{PhD}$

Film and media Studies Section

Department of Media, Cognition and Communication

University of Copenhagen, Denmark

linenp@hum.ku.dk 